\title{
CIVIC VIRTUE AND \\ THE SOVEREIGNTY \\ OF EVIL
}

Derek Edyvane

School of Politics

and International Studies,

University of Leeds

Izvorni znanstveni rad

Primljeno: ožujak 2012.

\begin{abstract}
Summary The author explains the main categories and arguments introduced in his forthcoming book Civic Virtue and the Sovereignty of Evil: Political Ethics in Uncertain Times. He offers a dualist account of public morality, contrasting aspirational with preventive politics and suggesting that the latter is often not given enough weight in contemporary political theory. He continues with introducing the idea of sovereignty of evil and clarifying its role in constituting preventive civic virtues. The author concludes by arguing that making sense of practices of civic virtue in conditions of conflict and insecurity should be in terms of the preventive austerity ethic.
\end{abstract}

Keywords preventive politics, evil, civic virtues, conflict, austerity

\section{Introduction}

We are often told that we live at a time of ethical crisis. There is something "profoundly wrong with the way we live today", writes Tony Judt (2010a: 1). We have somehow lost our ethical bearings; "we have no language to use. 'This is wrong' has long since ceased to have validity as a political statement" (Bunting, 2010: 5). And this leaves us, Michael Sandel contends, in a state of "restless impatience with politics as it is". We need to revive the language of civic virtue; we need urgently to initiate a process of "moral and civic renewal" in Western democracies. And, for Sandel, the way to achieve such renewal is by the cultivation of a "politics of the common good" directed at the pursuit of the good society (Sandel, 2009).

But it is very hard to see how any such process of renewal might come about. If ours is a time of ethical crisis, then it is also a time of financial crisis, a time of gnawing insecurity and deep moral conflict. In these circumstances of profound uncertainty, Sandel's appeal to the politics of the common good can all too easily assume a kind of fairytale quality. Our turbulent times have prompted many people to think less about the good life and the good soci- 
ety and more about their basic needs for safety and reassurance. And this sense of mismatch between the preoccupations of the academics on the one hand and the real social and political problems we face on the other can paradoxically function to exacerbate the ethical crisis by fostering feelings of moral despair. If the academics have nothing constructive to say about public morality when insecurity is rife and the 'common good' is incomprehensible to us, then perhaps we must conclude that there is no basis for public morality in such conditions. Alternatively, the sense of mismatch will prompt charges of intellectual irresponsibility. Polite discussion of the politics of the common good may be an entertaining diversion for middle class academics with nothing more pressing to think about, but they are guilty, so the criticism runs, of fiddling while Rome (or Athens or London) burns.

My aim in this short introduction is to sketch a rather different model of the structure of public morality and in so doing to show how practices of civic virtue may continue to make sense in circumstances of pronounced moral conflict and insecurity. ${ }^{1}$ In this way, I want to resist the counsel of despair that there is no basis for public morality in uncertain times. However, I shall contend that in order to appreciate what basis there is, we will need to inaugurate a fairly dramatic change of perspective. Political philosophy has typically concentrated too heavily on positive moral notions, on common goods and civic ideals, and a fundamental reorientation is now re-

1 This is a very brief summary, then, of an argument I have elaborated at much greater length and depth in my book, Civic Virtue and the Sovereignty of Evil (Edyvane, 2012). quired. In her book, The Sovereignty of Good, Iris Murdoch remarks that "good political philosophy is not necessarily good moral philosophy" (Murdoch, 2001: 79). I submit that the reverse is also true: in the domain of public morality, we must acknowledge the sovereignty of evil.

\section{The Dualistic Model of Public Morality}

Whilst many authors agree that we need to rehabilitate civic virtue in public life, their opinions diverge in a rather puzzling way when it comes to the question of what the point of civic virtue is meant to be. Many, like Sandel, argue that the point of civic virtue is to facilitate the pursuit and realisation of the good society: the better kind of politics we need is a politics oriented less to the pursuit of individual self-interest and more to the pursuit of the common good (Sandel, 2009). But others, and Judt is a prominent example here, suppose that the point of public morality is quite different. Instead of helping us to pursue the common good, its central point and purpose is to avert disaster: to prevent the "complete breakdown of liberal institutions" and the "utter disintegration of the democratic consensus" (Judt, 2009). Thus, while Sandel associates civic virtue with the politics of hope, Judt associates it with the politics of fear.

Now, it is tempting to see this as nothing more than the reflection of Sandel's optimism and Judt's pessimism. In this way, Michael Walzer suggests that the politics of hope and the politics of fear are really just two sides of the same coin. In fact, Walzer argues that the politics of fear depends on the politics of hope (Walzer, 1996). A fearful politics needs to be fearful on behalf of something. And 
so, we might presume, Judt's fearful view of public morality is fearful on behalf of something like Sandel's hopeful view of public morality. In this way, Walzer's account suggests a neat continuity, even symmetry, between the positive and the negative aspects of public morality.

But I dispute that view. I propose instead a dualistic model of public morality whereby public life is the awkward amalgamation of two entirely distinct modes of political activity. More precisely, my suggestion is that the distinction between the politics of hope and the politics of fear is cut across by a second distinction between aspirational political activity, which is oriented towards the realisation of ideals, and preventive political activity, which is oriented towards the prevention of great evils. Thus, I propose that public morality is composed of two modes of activity - aspiration and prevention - and that each of those two modes has a positive (or hopeful) face and a negative (or fearful) face. While there may be symmetry across the hope/ fear divide, there will be conflict across the aspiration/prevention divide. Thus, on my account, Sandel and Judt are to be understood (rather crudely) as representatives of two wholly different political agendas: Sandel is to be associated with the hopeful face of the politics of aspiration, whereas Judt is to be associated with the fearful face of the politics of prevention. There is no reason to suppose that their respective ethical agendas will display any kind of continuity or symmetry.

The attraction of the dualistic model is that it enables us to make better sense of situations in which positive and negative ethical agendas for public life conflict. Sometimes acting in order to avert disaster and the catastrophic collapse of democratic institutions will demand the violation and betrayal of one's ethical aspirations for public life. We see this clearly enough in practices of toleration. Often regarded as a practice integral to the health of a liberal democracy, toleration may well require us to betray our ideal vision of society and of those who would inhabit it for the sake of getting along peaceably with those among whom we do as a matter of fact live. In such cases there seems to be asymmetry between the politics of hope and the politics of fear. This sort of antagonism is hard to understand on Walzer's monistic model of public morality; but it makes a lot more sense on the dualistic model. The dualistic model suggests that in this situation the tolerant agent finds herself torn between the claims of the hopeful face of the politics of aspiration (which dictate intolerance of those who have no place in her social and political ideal) and the claims of the fearful face of the politics of prevention (which dictate toleration for the sake of civic peace and, at the limit, for the prevention of civil war).

\section{The Sovereignty of Evil}

The dualistic model of public morality also helps us better to comprehend practices of civic virtue in the sorts of conditions I described at the outset, conditions of uncertainty and of conflicting ethical aspirations. Because we are thinking now in terms of two discrete schemes of public morality - the aspirational and the preventive - it is quite possible that, while there is disagreement and even conflict on the aspirational side, there may yet be consensus on the preventive side. In other words, we can make sense of practices of civic virtue in conditions of conflicting ethical aspirations inso- 
far as we regard those practices as being oriented to the prevention of commonly recognised evils rather than the pursuit of aspirations (which are the subject of profound disagreement).

Note that the argument here is not merely that we ought to take the idea of evil more seriously when we think about public morality. We need to be clear about what is meant by 'evil' in this context. I suggest that there is a 'basic' notion of evil which functions simply as a description of terrible human suffering. The great evils of human life are those states of affairs in which such suffering occurs. Within this category of basic evil there is an important distinction to be made between 'contingent basic evils' and 'sovereign basic evils'. Contingent basic evils are those that are identifiable only in the light of an antecedently acknowledged scheme of particular positive values, whereas sovereign basic evils are immediately felt as evils by any normally responsive person.

For example, then, many egalitarians will regard as a basic evil any inequalities of wealth and status that are not arranged to the benefit of the least well off. On my account, the evil of inequality so described is a contingent evil. Such inequality is not immediately felt as a great evil. In order to perceive inegalitarian social arrangements as evil, it is first necessary to recognise a particular way of life and a set of moral ideas that attach value to equality. Only in the light of that positive valuation does the evil of equality violated become apparent. Those who uphold conservative moral beliefs, and who place value on the preservation of traditional social (and economic) hierarchies, cannot be expected to see such inequality as an evil.
The basic evil of extreme poverty is different. Think of the visceral depictions of poverty in John Steinbeck's The Grapes of Wrath, like the "wasted face" and the "wide, frightened eyes" of the starving man described at the novel's end (Steinbeck, 2000: 476). Such images elicit immediate feelings of "aesthetic revulsion" quite independently of any prior understanding one might have of a particularly valued way of life from which extreme poverty constitutes a falling away. ${ }^{2}$ Indeed, circumstances of extreme poverty upset the very possibility of forming a stable set of moral beliefs of any kind, and egalitarians and conservatives will usually be united in their abhorrence of the very great evil of extreme poverty. Thus, the evil of poverty so described is not a contingent evil, but rather a sovereign evil of human life.

Alongside extreme poverty, other such sovereign evils might include the evils of disease, starvation, humiliation, abject despair and the mutilations of war. It is not unreasonable to contend that these evils are universal in human life and traceable to the features of our common humanity. This is not to say that everyone would necessarily agree on any particular list of the sovereign evils - we know perfectly well that they do not. The universalist's argument here would need to be that those who failed to recognise, say, the great evil of starvation had been somehow distracted from their natural feelings, perhaps by a theory - a set of religious or political beliefs that functioned to explain those feelings away (see Hampshire, 1999: 9). To be sure, this kind of response could never be decisive, but it does help to show why

\footnotetext{
2 The idea of 'aesthetic revulsion' is from Tony Judt (2012, ch. 9).
} 
it is not absurd to posit the universality of certain evils even in the face of factual disagreement about those evils.

The idea, then, is not simply that we need to take the concept of evil more seriously, but more specifically that we have to acknowledge the category of sovereign evil, which corresponds to the preventive ethic, as contrasted with the category of contingent evil, which corresponds to the aspirational ethic. In conditions of divergent ethical aspirations, conceptions of contingent evil will also diverge and so the appeal to contingent evil does not provide a compelling basis for public morality in such conditions. Conceptions of sovereign evil, by contrast, need not diverge (because asymmetric to aspirations) and could therefore provide a secure basis for practices of civic virtue in the uncertain times in which we now live.

\section{Preventive Virtue}

In the prevention of sovereign basic evils, it is possible to discern a distinctive form of civic virtue. Stuart Hampshire writes that by reflecting on the great (sovereign) evils of human life "one may come to understand better, and to identify more distinctly, the ordinary and indispensable decencies of public life which may be overlooked in the projection of liberal ideas of social improvement" (Hampshire, 1989: 68). In this context, civic virtue describes the habits, dispositions and qualities of character that citizens need to display if they are to contribute to the prevention or mitigation of sovereign evil. In this way, civic virtue loses the aspirational quality with which it is so often imbued and takes on a more prohibitive character, yielding a public morality of ordinary, everyday decency.
More concretely, we can see the sort of preventive ethic I have in mind here at work in the context of 'austerity Britain' after the Second World War. While nowadays austerity is usually understood as an essentially economic condition, one that describes a falling away from conditions of prosperity, in the post-war years austerity "aspired to a public ethic" (Judt, 2010b). As the Labour Party manifesto of 1945, Let Us Face the Future, declared: "We need the spirit of Dunkirk and the Blitz sustained over a period of years" (quoted in Kynaston, 2007: 21-22). Here austerity is not a description of the desolate economic condition in which people found themselves, but rather a particular way of responding to that condition, a particular way of living with scarcity, vulnerability and uncertainty that was meant to be choiceworthy and admirable.

The austerity ethic comprised the virtue of austerity itself, a virtue of self-denial, moral fortitude and self-sacrifice. And it also incorporated a cluster of other closely associated virtues including justice, civic friendship and social hope. The key interest of the austerity ethic and its associated virtues is that they were fundamentally preventive in their orientation. Few apart from the most ambitious of the social planners in the Labour government supposed that the practice of austerity was a means to the realisation of the ideal society. To interpret austerity in that way would be to confuse it with asceticism. Asceticism is associated with aspirational morality and is to be understood as a programme of self-denial and self-sacrifice implemented as a means to the realisation of some great good, such as salvation in the case of some religious ascetics. Austerity is quite different. It is still 
an ethical concept, but it is one associated not with the pursuit of aspiration, but rather with the prevention of sovereign evil. We can see this clearly enough in the Labour Party manifesto which called for the practice of austerity not in order to realise the ideal society, but in order to insure "against rainy days" (Kynaston, 2007: 21). Likewise, William Beveridge's 'Social Insurance and Allied Services Report', which paved the way for the creation of the National Health Service in Britain, derived its impetus not from some sort of utopian social democratic vision, but rather from the need to tackle the five Giant Evils of Want, Disease, Ignorance, Squalor and Idleness (Beveridge, 1942/n.d.).

The preventive virtues I have associated with the austerity ethic may at first blush seem entirely familiar and not very distinctive at all. The virtue of justice has a central place in almost every aspirational morality one might care to mention. Civic friendship and social hope are slightly less familiar, but still very far from unheard of in aspirational contexts. However, in the context of the preventive ethic, these familiar virtues take on an altogether different colouration. No longer is justice to be interpreted as a means to the "realistic utopia" of a "well-ordered society", but is instead to be interpreted in procedural terms, as a way of dealing with conflict so as to prevent the catastrophic collapse of civilised life into conditions of anarchy and civil war. Similarly, civic friendship is not interpreted as a means to the realisation of some romantic, communitarian ideal, but instead as a bulwark against the enmity, hostility and misan-

3 Of course, the language here is that of John Rawls (1971; 1996). thropy that might otherwise poison the diverse and antagonistic democratic collective. And finally, the virtue of social hope is not to be understood in terms of the grandiose, even messianic, utopian hopes of aspirational social movements past and present (there was, of course, more than a trace of that sort of thing in the rhetoric of the Obama presidential campaign), but instead as a much more mundane 'ordinary hope' of the kind that sustains most friendships and families and consists primarily in the simple disposition to resist the sovereign evil of abject despair, and to keep going.

To be sure, this catalogue of preventive virtues will seem extremely modest and minimalistic when set alongside the catalogues of virtues associated with all manner of aspirational moralities, and that may in turn fuel a sense of disappointment among those who have called for the rehabilitation of civic virtue in public life. To that sort of concern I would respond first that, modest though it may be, it is the best we can reasonably hope for in the social and political conditions in which we find ourselves. And, secondly, I would suggest that it is in any case the wrong contrast to be making. The preventive ethic will always seem thin and disappointing when set alongside one's preferred aspirational ideal, but we should ask ourselves instead how the preventive ethic looks when set alongside a world of desolation and terror in which life is everywhere nasty, brutish and short. That is the salient contrast from the perspective of the preventive ethic. And from that perspective, the practice of preventive virtue may seem a rather more momentous achievement and, what is more, an achievement worth fighting for. 


\section{Conclusion}

If we are to make sense of practices of civic virtue in conditions of conflict and insecurity, then it will be in terms of the preventive austerity ethic or not at all. The practices of ordinary, everyday decency in which democratic citizens sometimes participate cannot be interpreted as practices aimed at the pursuit of the common good or the good society. In contexts of insecurity and conflicts of aspiration those sorts of pursuits seem irrelevant at best, and possibly just incoherent. That realisation can easily provoke a sense of moral despair and the belief that there is no ground at all for civic virtue in the social and political conditions in which we find ourselves. By articulating the dualistic model of public morality and the category of sovereign evil, I have attempted to assuage that concern and to resist the counsel of despair. It is possible to make sense of practices of ordinary decency in conditions of moral conflict and insecurity in so far as we are able to interpret those practices as being oriented not to the pursuit of aspiration, but instead to the prevention of the sovereign evils of human life.

\section{REFERENCES}

Beveridge, W. (1942/n.d.) Social insurance and allied services report. $B B C$. http://news.bbc.co.uk/1/shared/bsp/ hi/pdfs/19_07_05_beveridge.pdf

Bunting, M. (2010) Introduction: Fanning the flames of a vital debate. $\mathrm{Ci}$ tizen Ethics Network. http://www.citizenethics.org.uk/docs/EthicsTemplateDoc.pdf

Edyvane, D. (2012) Civic virtue and the sovereignty of evil. London: Routledge.

Hampshire, S. (1989) Innocence and experience. London: Penguin.

Hampshire, S. (1999) Justice is conflict. London: Duckworth.

Judt, T. (2009) What's living and what's dead in social democracy. New York Review of Books 56 (20), http://www. nybooks.com/articles/23519

Judt, T. (2010a) Ill fares the land: A treatise on our present discontents. London: Allen Lane.
Judt, T. (2010b) Austerity. New York Review of Books, 13 May. http://www. nybooks.com/articles/archives/2010/ may/13/austerity/

Judt, T. (2012) Thinking the twentieth century, with T. Snyder. Kindle edition. London: Heinemann.

Kynaston, D. (2007) Austerity Britain: 1945-51. London: Bloomsbury.

Murdoch, I. (2001) The sovereignty of good. London: Routledge.

Rawls, J. (1971) A Theory of Justice. Cambridge, Mass.: Harvard University Press.

Rawls, J. (1996) Political liberalism. New York: Columbia University Press.

Sandel, M. (2009) The Reith Lectures: Markets and morals. BBC. http://www. bbc.co.uk/programmes/b00kt7sh

Steinbeck, J. (2000) The grapes of wrath. London: Penguin. 
Walzer, M. (1996) On negative politics. vision of Judith N. Shklar, ed. Bernard In: Liberalism without illusions: Es- Yack. Chicago: University of Chicago says on liberal theory and the political Press, 17-24.

\section{Građanska vrlina i suverenitet zla}

SAŽETAK Autor pojašnjava glavne kategorije i argumente koje zagovara u svojoj knjizi Civic Virtue and the Sovereignty of Evil: Political Ethics in Uncertain Times (knjiga izlazi u drugoj polovici 2012). Autor nudi dvojno razumijevanje javnog moraliteta, uspoređujući aspiracijsku s preventivnom politikom i argumentirajući da je preventivna politika često zanemarivana u suvremenoj političkoj teoriji. Nastavlja uvodeći ideju suvereniteta zla i pojašnjavajući njenu ulogu u konstituiranju preventivnih građanskih vrlina. Autor zaključuje tvrdeći kako se smisleno prakticiranje građanskih vrlina u uvjetima sukoba i nesigurnosti treba voditi preventivnom etikom.

KLJUČNE RIJEČI preventivna politika, zlo, građanske vrline, sukob, štedljivost 